\title{
Spontaneity of Speech Errors: A Diagnostic Psycholinguistic Case Study
}

\author{
Mohammad Awad Al-Dawoody Abdulaal ${ }^{1} \&$ Naglaa Fathy Mohammad Atia Abuslema ${ }^{2}$ \\ ${ }^{1}$ Department of English, College of Sciences \& Humanities, Prince Sattam Bin Abdulaziz University, Al-Kharj, \\ Saudi Arabia \\ ${ }^{2}$ Department of Mental Health, Faculty of Education, Port Said University, Port Said, Egypt \\ Correspondence: Mohammad Awad Al-Dawoody Abdulaal, Department of English, College of Sciences and \\ Humanities, Prince Sattam Bin Abdulaziz University, P. O. Box: 82, Al-Kharj 11942, Saudi Arabia. E-mail: \\ ma.abdulaal@psau.edu.sa
}

Received: January 20, 2020 Accepted: February 29, 2020 Online Published: March 17, 2020

doi:10.5539/ijel.v10n3p92 URL: https://doi.org/10.5539/ijel.v10n3p92

\begin{abstract}
The aim of this study is to use speech errors as a verbal means of communication to clarify the psychological aspects of George W. Bush's character. Bush's character is chosen for being highly controversial, having received the lowest approval rating in 2008 and the highest approval rating after the September 11 attacks. To achieve the aim of this study, a psycholinguistic approach is adopted in addition to a speech production model set by Dell (1999), and Chang and Griffin (1999). Some of Bush's spontaneous errors are supposed to be collected, and then categorized from a psycholinguistic perspective and finally analyzed statistically. The main results of the study can be summed in the following points. (a) The phonological and morphological errors, caused by the psychological priming, reveal how much perplexity and confusion Bush has experienced. (b) Bush's Freudian slips - caused by psycho-physiological factors, such as fatigue, excitement, and distraction — reveal the fact that he is not an open outright president as he represses many thoughts and feelings more than he shows. (c) Bush's syntactic errors, caused by the improper lexical insertion, reveal his poor linguistic competence; the matter that reveals low intelligence for many psychologists such as Pishghadam and Shams (2012). (d) The economical use of speech disfluencies, caused by problems in the recognition system, reveals that Bush has a tendency of rashness. That is, he may take rapid incorrect decisions that lead to catastrophes.
\end{abstract}

Keywords: spontaneity, slips of the tongue, diagnostic study, psycholinguistic study, spoonerism

\section{Introduction}

George. W. Bush, 43rd president of the United States, receives much criticism and flattery during his presidency that lasts from 2001 to 2009. Some psychologists, authors, political commentators, journalists and analysts — such as Woodward (2002), Black (2004), Andersson (2005), Long (2009), and Judis (2005) — point out that Bush attempts to place himself as a legendary ethical leader who evokes past events to urge the Americans to keep up fighting terrorism for the sake of liberty and democracy. Others, such as Pfiffner (2003), Greene (2006), Rodriguez (2006), Kushner and Gershkoff (2005), assert that Bush is a manipulative cunning lying president who attempts to set a false link between 9/11 attacks and Saddam Hussein. In addition to his manipulative skills, Pfiffner (2003), Rodriguez (2006), and Kushner and Gershkoff (2005) also assert that Bush is a president with a bias for action rather than deliberation. The contrasted controversial views concerning Bush's character stirs the researcher to examine the aspects of Bush's personality from a psychological perspective, using a psycholinguistic tool, speech errors.

\subsection{A Psycholinguistic Perspective of Bush's Personality}

The results of the studies of Andersson (2005) and Judis (2005) reveal some aspects of Bush's personality. These aspects are revealed via President George W. Bush's conscious and skillful employment of certain devices such as religious references and historical symbols in his speeches. As a matter of fact, the use of these devices is peculiar as it matches with the line of American political rhetoric. What can also be noticed after reading these studies is that Bush relies heavily on American sense of patriotism. In other words, Bush reminds the Americans with their great history. The use of these devices spotlights some aspects of Bush's psychological personality. He 
wants to portray himself as a leader who studies the past and the present to encounter the future dangers facing America. He also wants to set himself as a leader of the twenty-first-century crusades launched against the barbarian terrorists. Like Andersson (2005) and Judis (2005), Pfiffner (2003), adopting a psychological approach, examines Bush's personal traits that can be deduced from his speeches. Pfiffner (2003, p. 161) argues that Bush's rhetoric reveals three personal traits: [1] "bias for action rather than deliberation", [2] "moral certainty over strategic calculation"; and [3] "personal approach to politics".

\subsection{Research Questions}

The researcher attempts to analyze Bush's speech errors to define the psychological peculiarities of Bush's character. Therefore, the researcher intends to find answers for the following questions:

1) What are the categories of errors made in Bush's spontaneous speeches?

2) What are the psycholinguistic interpretations of Bush's speech errors?

3) What can speech errors reveal about Bush's character?

\section{Method}

Speech errors, the research method employed in this study, can be defined as unintentional linguistic innovations. Further, they are defined as involuntary deviation in performance from the one's current phonological, grammatical or lexical intention (Fromkin, 1973). Fromkin's corpus of speech errors is employed for examining and categorizing George W. Bush's speech errors into groups including (a) cognitive intrusions, (b) phonological errors, (c) morphological errors, (d) syntactic errors, (e) semantic errors, and (f) speech disfluencies. Fromkin's corpus is widely used by psycholinguists when analyzing speakers' speech errors. It is worth noting that the focus is supposed to be on Bush's errors produced in spontaneous rather than previously prepared speeches.

\subsection{Research Procedures}

The research undertakes the following procedures. (a) The researcher looks for Bush's spontaneous utterances that have speech errors. (b) Depending on Fromkin (1973), Clark (1977), Carroll (1986), Garnham, (2013) and Levelt (1989), the researcher sets Bush's speech errors into categories. (c) The psycholinguistic approach is then used to interpret Bush's speech errors. (f) The researcher begins to draw a character sketch for Bush depending on the data analyzed.

\subsection{Research Design}

In this study, the researcher used the mixed research design to solve the research problem and answer the research questions raised in this study. There are two basic types of research paradigms: (1) quantitative research and (2) qualitative. The researcher used the two research approaches by transforming the descriptive data collected to quantitative, which underwent deep analysis by SPSS.

\section{Results and Data Analysis}

\subsection{Bush's Cognitive Intrusions}

(1) "If you want to build a big project and you can't get insurance because of what the terrorists have done for America, you can put the project aside.” (George W. Bush, Oakland County Airport, October 14, 2002)

\begin{tabular}{lll}
\hline Target & Error & Error Type \\
\hline To & For & Freudian slip \\
\hline
\end{tabular}

In 2002, George W. Bush took part in a rally at the Oakland County Airport. He delivered a speech on the impact of terrorism on US economy. He pointed out that the Americans should contemplate on what terrorists had done to America. He perhaps was thinking of the fact that America would soon control Iraq, which had $\$ 10$ trillion in oil reserves, second only to Saudi Arabia.

(2) "After standing on the stage, after the debates, I made it very plain, we will not have an all-volunteer army. And yet, this week-we will have an all-volunteer army. Let me restate that. We will not have a draft (i.e., compulsory enrollment in the armed forces); No matter what my opponent (i.e., John Kerry) tries to tell people and scare them, we will have an all-volunteer army." (George W. Bush, Daytona Beach, October 16, 2004) 


\begin{tabular}{lll}
\hline Target & Error & Error Type \\
\hline $\begin{array}{l}\text { We will not have an } \\
\text { all-volunteer army }\end{array}$ & $\begin{array}{l}\text { We will have an } \\
\text { all-volunteer army }\end{array}$ & Freudian slip \\
\hline
\end{tabular}

In a presidential debate with John Kerry, Bush declared that the best way to avoid the draft (i.e., national conscription) was to vote for him. He pledged to oppose mandatory military service. He accused John Kerry of supporting the notion of national conscription. Bush mistakenly said "We will not have an all-volunteer army". He quickly corrected himself by saying "Let me restate that. We will not have a draft. The best way to avoid a draft is to vote for me."

(3) Well, I mean that a defeat in Iraq will embolden the enemy and will provide the enemy-more opportunity to train, plan, to attack us. That's what I mean. There-it's-you know, one of the hardest parts of my job is to connect Iraq to the war on terror. I believe it. As I told you, Osama bin Laden believes it (Bush, Washington DC, 2006).

\begin{tabular}{lll}
\hline Target & Error & Error Type \\
\hline $\begin{array}{l}\text { I am sure that there is a connection } \\
\text { between Iraq and the war on terror. }\end{array}$ & $\begin{array}{l}\text { One of the hardest parts of my job is to } \\
\text { connect Iraq to the war on terror }\end{array}$ & Freudian slip \\
\hline
\end{tabular}

In an interview with Katie Couric aired on CBS Evening News, Bush said that one of the hardest parts of his job was to connect the Iraqi regime to the war on terror. His comments with Katie Couric totally contradicted previous statements by members of his administration. Bush in his interview with Katie Couric said that he just believed that there was a connection between Saddam Hussein and the terrorist September 11th attacks. The implication was that the war on Iraq was groundless and was not for the sake of fighting terrorism. It was for the sake of Iraqi oil as many commentators said.

\subsection{Phonological Errors}

(4) "If the terriers and bariffs are torn down, this economy will grow." (George Bush, Rochester, New York, January 7, 2001)

\begin{tabular}{lll}
\hline Target & Error & Error Type \\
\hline tariffs and barriers & terriers and bariffs & Spoonerism \\
\hline
\end{tabular}

At a press conference in 2001, Bush was asked about how he would make the American economy rapidly grow. He stated that America had free trade agreements with some countries, such as Israel, Mexico, and Canada. He declared that he would sign more free trade agreements with developing countries, such as Jordan and Morocco, in addition to the young democracies of Central America. He also declared that he would eliminate barriers and tariffs between the United States and many countries all over the world. However, instead of saying tariffs and barriers he said 'terriers and barrifs'.

(5) "My pan plays down an unprecedented amount of our national debt." (George W. Bush, Washington D.C., 27 February, 2001)

\begin{tabular}{lll}
\hline Target & Error & Error Type \\
\hline plan pays & pan plays & Perseveration \\
\hline
\end{tabular}

In his address to a joint session of the congress in 2001, Bush tried to explain how he would pay down the national debt. He intended to increase spending for Social Security and Medicare and other entitlement programs by $\$ 81$ billion. He intended to increase spending for discretionary programs by 4 percent above the rate of inflation. He said that if he managed to fulfill his plan, he would be able to pay down much of the national debt. However, instead of saying 'my plan pays down', he said 'my pan plays down', producing a phonological error, 
categorized psycho-linguistically as Perseveration.

(6) "I want to reinnerate what I said the other day. Our policy is to deny sanctuary to terrorists anyplace in the world." (George Bush, White House, March 13, 2002)

\begin{tabular}{lll}
\hline Target & Error & Error Type \\
\hline reiterate & Reinnerate & Insertion of a new syllable /Syllable substitution \\
\hline
\end{tabular}

On March 13, 2002, in the White House, in a news conference, Bush was asked how the increased violence between the Israelis and the Palestinians would affect his efforts to convince the Arab allies that the Iraqi regime had no choice but to accept unconditional inspection for weapons of mass destruction. Bush answered that he knew that the unrest in the Middle East would create unrest throughout the region. He vowed that he would interfere to set peace between the Israelis and the Palestinians. However, he implicitly warned the Arab countries in general and the Palestinians in particular form giving shelter to terrorists. However, instead of saying that he would 'reiterate' his views concerning harboring terrorists, he said 'reinnerate', substituting the syllable '-it-' with the syllable 'in-', producing a phonological error.

\subsection{Morphological Errors}

(7) "I don't have to accept their tenants. I was trying to convince those college students to accept my tenants. And I reject any labeling me because I happened to go to the university." (George W. Bush, February 23, 2000)

\begin{tabular}{lll}
\hline Target & Error & Error Type \\
\hline Tenets & Tenants & Malapropism \\
\hline
\end{tabular}

The excerpt in (7) above was said by Bush as a comment on his controversial visit to Bob Jones University in 2000 during his election campaign. Bob Jones University is the largest conservative Christian institution in the USA. It proclaims for fundamentalism. But after Bush's speech in which he said that he looked forward to publicly defend the conservative philosophy, he was criticized by Catholics because of the school's position on Catholicism, and by Blacks because of the school's ban on interracial dating. Bush then claimed that he deeply regretted appearing in the university. He contended that his speech was misunderstood. He added that his visit to Bob Jones university did not mean that he hold their tenets (i.e., principles and beliefs). However, instead of saying 'tenets', he said 'tenants'.

(8) "We cannot let terrorists and rogue nations hold this nation hostile or hold our allies hostile." (George W. Bush, Des Moines, IA, August 21, 2000)

\begin{tabular}{lll}
\hline Target & Error & Error Type \\
\hline Hostage & Hostile & Malapropism \\
\hline
\end{tabular}

The excerpt in (8) above was said by Bush as a comment on US proposed Missile Defense Program. Bush was asked by a reporter during his election campaign whether he was for or against the National Missile Defense Program. Actually, this program is a mechanism which can detect and destroy a missile before it can cause any harm. This program can shield America against any kind of missiles. Therefore, for Bush, there was no chance for rogue nations to hold America hostage; the reference was to Iran and North Korea.

(9) "The law I sign today directs new funds and new focus to the task of collecting vital intelligence on terrorist threats and on weapons of mass production." (Washington, D.C., November 27, 2002.).

\begin{tabular}{lll}
\hline Target & Error & Error Type \\
\hline destruction & production & Malapropism \\
\hline
\end{tabular}


In 2002, in a news conference, Bush declared that he set up "The National Commission on Terrorism" (Kean \& Hamilton, 2004, p.479). This commission was created by the Congress, with a bill that was signed later into law by Bush. It was also known as the $9 / 11$ Commission. It was set up to prepare a full report on the circumstances surrounding the September-11th attacks. The commission was asked to give recommendations to prevent future attacks by weapons of mass destruction. However, Bush slipped saying production rather than destruction.

(10) "I am mindful not only of preserving executive powers for myself, but my predecessors as well." (George W. Bush, Washington, D.C., January 29, 2001)

\begin{tabular}{lll}
\hline Target & Error & Error Type \\
\hline successors & predecessors & Malapropism \\
\hline
\end{tabular}

George W. Bush, in 2001, expressed his unwillingness to revoke Bill Clinton's pardon of Marc Rich, an international commodities trader, financier and businessman. He was accused of tax evasion and of illegally making oil deals with Iran during the Iran hostage crisis. He received a controversial presidential pardon from U.S. President Bill Clinton on January 20, 2001, Clinton's last day in office. Bush asserted that he and his successors should respect executive powers. However, instead of saying successors, he said predecessors.

(11) "We need an energy bill that encourages consumption." (George Bush, Trenton, New Jersey, September 23, 2002)

\begin{tabular}{lll}
\hline Target & Error & Error Type \\
\hline conservation & consumption & Malapropism \\
\hline
\end{tabular}

In September 2002, Bush addressed the American people about his energy concerns. He focused on energy consumption and its dangers on the American economy. Bush asked the Congress to quickly pass an energy bill. He believed that such an energy bill would help his administration to provide the Americans with more jobs. He repeated the notion that the Americans needed an energy bill that encourages energy conservation. However, instead of saying conservation or rationalization, he slipped saying consumption.

(12) "Really proud of it. A great campaign. And I'm really pleased with the organization and the thousands of South Carolinians that worked on my behalf. And I'm very gracious and humbled." (George W. Bush, South Carolina, February 20, 2000)

\begin{tabular}{lll}
\hline Target & Error & Error Type \\
\hline grateful & gracious & Malapropism \\
\hline
\end{tabular}

On February 19, 2000, George Bush achieved a sweeping victory over John McCain in South Carolina, proving that he was the unmistakable front-runner for the Republican presidential nomination. On February 20, Bush thanked the head of his presidential campaign in South Carolina, Mary Corinne Roberts, later appointed in his presidential team. In addition, he thanked the members of his presidential campaigns. But he slipped saying that he was gracious to the head and the members of his presidential campaign instead of saying that he was grateful.

(13) "Anyway, I'm so thankful and so gracious-I'm gracious that my brother Jeb is concerned about the hemisphere as well.” (George Bush, Miami, Florida, June 4, 2001)

\begin{tabular}{lll}
\hline Target & Error & Error Type \\
\hline grateful & Gracious & Malapropism \\
\hline
\end{tabular}

On June 4, 2001, President George W. Bush met the national park service officers at the Royal Palm Visitors Center in Florida. Bush announced two agreements that would preserve Florida's environment for generations to come. He declared that he supervised an agreement between the Departments of Interior and Justice and some 
private energy companies to buy back oil and gas leases from Florida. Further, he announced an important agreement to buy back drilling rights in some tropical areas in Florida. At the end of his speech, he thanked his brother, Jeb Bush, the governor of Florida (1999 to 2007), for taking care of the environment in his state. However, instead of saying that he was grateful to his brother, the governor of Florida, he said that he was gracious, an error that constantly repeated in Bush's spontaneous speeches.

(14) "What I am against is quotas. I am against hard quotas, quotas they basically delineate based upon whatever. However, they delineate, quotas, I think, vulcanize society. So, I don't know how this fits into what everybody else is saying, their relative positions, but that's my position." (George Bush, January 21, 2000)

\begin{tabular}{lll}
\hline Target & Error & Error Type \\
\hline Balkanize & vulcanize & Malapropism \\
\hline
\end{tabular}

In 2000, in a news conference, a correspondent called Ken Herman asked Bush about his opinion concerning the American quota system (i.e., a system, originally determined by legislation in 1921, limiting by nationality the number of immigrants who may enter the U.S. each year) (Martin \& Midgley, 2003). Bush said that for the Americans to succeed and actively affirm access to the American dream, they should revoke this system. The quota system, according to George Bush, would lead to an American balkanization. That is, it would divide America into smaller hostile states. However, instead of saying that the quota system would balkanize America, bush said vulcanize America.

(15) "The enemy understands a free Iraq will be a major defeat in their ideology of hatred. That's why they're fighting so vociferously." (George Bush, Coral Gables, Florida, September 30, 2004)

\begin{tabular}{lll}
\hline Target & Error & Error Type \\
\hline fiercely & vociferously (i.e., loudly) & Malapropism \\
\hline
\end{tabular}

In 2004, in the first presidential debate with John Kerry, Bush was asked if there were any possibilities that America would be exposed to 9/11-type terrorist attacks. Bush replied, with much confidence, that there were no chances that such attacks would take place again. He asserted that America in 2004 became much safer than that in 2001 thanks to the security reforms that he had introduced to the general American security system. He also added that Al-Qaeda fought fiercely since it absolutely positive that it was about to be completely defeated in Iraq. However, instead of saying that Al-Qaeda fought fiercely he mistakenly said vociferously.

\subsection{Bush's Syntactic Speech Errors}

(16) "Rarely is the question asked: Is our children learning?" (George W. Bush, Florence, South Carolina; January 11, 2000).

\begin{tabular}{lll}
\hline Target & Error & Error Type \\
\hline Are & Is & Subject verb agreement \\
\hline
\end{tabular}

The excerpt above marked the appearance of the term Bushism. During his presidential campaign against John McCain for the Republican presidential nomination, Bush delivered a speech in Florence, South Carolina. In this speech, Bush wondered if the American children received the proper education. The lack of subject-verb agreement attracted the listeners.

(17) "We can have filters on internets where public money is spent." (George Bush, October 17, 2000)

\begin{tabular}{lll}
\hline Target & Error & Error Type \\
\hline Internet & Internets & adding plural 's' to a non-count noun \\
\hline
\end{tabular}


The first time Bush used the word internets was in his third presidential debate against Al Gore on October 17, 2000. During the debate, an audience member asserted that he was concerned about the spread of sexually explicit movies among the youths. The audience member wanted to know how Bush would face such a problem. Bush said that this problem could have been faced by using filters on the internet. Nonetheless, he grammatically slipped saying internets rather than internet, an error that constantly repeated in his speeches.

(18) "Yes, that's a great question. Thanks. I hear there's rumors on the, uh, internets that we're going to have a draft" (George Bush, Saint Louis, Missouri, 2004).

\begin{tabular}{lll}
\hline Target & Error & Error Type \\
\hline internet & Internets & Adding plural 's' to a non-count noun \\
\hline
\end{tabular}

In 2004, during a debate against John Kerry, Bush frequently used the word internets in response to an audience member's question about a potential military draft. The audience member asked about how Bush would maintain the American military presence around the world without imposing a draft. Bush replied that there were rumors on the internet that he would impose a draft. However, he again used the plural form of the uncountable word internet.

(19) "Information is moving - you know, nightly news is one way, of course, but it's also moving through the blogosphere and through the internets." (George Bush, Washington, D.C., May 2, 2007)

\begin{tabular}{lll}
\hline Target & Error & Error Type \\
\hline Internet & Internets & adding plural 's' to a non-count noun \\
\hline
\end{tabular}

In 2007, Bush delivered a speech to the Associated General Contractors of America. He discussed the troubles facing the American economy and the rising violence against the American troops in Iraq. He pointed out that information about the casualties of the American army spread via blogospheres and internet. However, he used the plural form of the word internet for a third time.

(20) "Afghanistan is the most daring and ambition mission in the history of NATO." (George Bush, Bucharest, Romania, April 2, 2008)

\begin{tabular}{lll}
\hline Target & Error & Error Type \\
\hline Ambitious & Ambition & Wrong use of a pre-modifier of a noun \\
\hline
\end{tabular}

Bush opened a meeting of NATO leaders in Romania by urging the American allies to "maintain their resolve and finish the fight" in Afghanistan and to strengthen their military forces to fight Al-Qaeda and other terrorist groups around the world. Bush described the NATO's mission in Afghanistan as an ambitious one. Nevertheless, he mistakenly employed the noun ambition rather than the adjective ambitious to describe the NATO's mission in Afghanistan.

(21) "You teach a child to read, and he or her will be able to pass a literacy test" (George Bush, Tennessee, February 21, 2001).

\begin{tabular}{lll}
\hline Target & Error & Error Type \\
\hline she & her & Misuse of pronouns \\
\hline
\end{tabular}

On February 21, 2001, Bush gave an important speech at Townsend Elementary School in Tennessee. He declared that he would introduce many educational reforms. He pointed out that education was given much priority by his administration. He also proposed additional spending for a national reading program. Nevertheless, he made a grammatical mistake while elaborating the significance of his program. He mistakenly employed the object pronoun her instead of the subject pronoun she, using the object pronoun as a subject to the 
verb phrase will be able to pass.

(22) "As yesterday's positive report card shows, childrens do learn when standards are high and results are measured" (George W. Bush, 2007)

\begin{tabular}{lll}
\hline Target & Error & Error Type \\
\hline children & childrens & Adding plural 's' to an irregular plural noun \\
\hline
\end{tabular}

On September 26, 2007, Bush, surrounded by children from a public school, bragged about the success of his education initiative. Nevertheless, while bragging about his educational achievements, Bush made a grammatical error. He added the plural '-s' morpheme to an irregular plural word.

(23) "Laura and I really don't realize how bright our children is sometimes until we get an objective analysis" (George W. Bush, Meet the Press, April 15, 2000)

\begin{tabular}{lll}
\hline Target & Error & Error Type \\
\hline children are & children is & Subject verb agreement \\
\hline
\end{tabular}

At a television interview, Bush was asked about the educational reforms that he would undertake in case of becoming the president of the United States. He first explained his reading initiative program, and then, began to discuss the reforms he introduced to the educational system in Texas when he was a governor. He bragged with the intelligence of his children who were educated in Texas schools. However, he made a grammatical mistake. He used a singular verb after an irregular plural word.

(24) "We talked about fighting terror. The United States has suffered terrorist attacks on its soil, as have Russia." (George W. Bush, 2008)

\begin{tabular}{lll}
\hline Target & Error & Error Type \\
\hline so has Russia & as have Russia & Wrong use of 'so' as an adverb \\
\hline
\end{tabular}

In 2008, in a Russian city, Bush and Vladimir discussed the war on terrorism. Bush appreciated the rule played by Putin to convince Iran to have civilian nuclear power. He concluded that USA and Russia had to cooperate as the two countries had been exposed to many terrorist attacks in the past. Nonetheless, Bush made a grammatical mistake when he used the preposition 'as' instead of the adverb 'so'.

(25) "Then you wake up at the high school level and find out that the illiteracy level of our children are appalling." (George Bush, Washington, D.C., January 23, 2004)

\begin{tabular}{lll}
\hline Target & Error & Error Type \\
\hline is & Are & Subject-verb agreement \\
\hline
\end{tabular}

Bush promised the Americans to make educating every child his top domestic priority during his second term. He proposed a comprehensive plan to improve overall student performance and close the achievement gap between rich and poor students in the American public schools. He proposed a law called No Child Left Behind Act that would improve the appalling educational level of the American children. However, while explaining the merits of such a law, he slipped using a plural verb, 'are', with a singular subject, 'the illiteracy level'.

\subsection{Semantic Errors}

(26) There's a lot of good people - there's a lot of good people, a lot of good people who wear the uniform at the local level, working hard to secure the homeland. A lot of good firefighters and EMS and police officers spend a lot of time, a lot of time worrying about you and your health. (Bush, New Jersey, 2002)

(27) "You'll hear, we're going to spend - the government is going to spend the government money here, and the 
government is going to spend the government here.” (Bush, New Jersey, 2002)

\begin{tabular}{lll}
\hline Target & Error & Error Type \\
\hline $\begin{array}{l}\text { The underlined words should } \\
\text { be economized. }\end{array}$ & $\begin{array}{l}\text { The underlined words are } \\
\text { repeated many times. }\end{array}$ & Repetition \\
\hline
\end{tabular}

In 2002, Bush addressed the American people about the challenges that the United States of America was facing at that time. He proposed setting up a Homeland Security Department. However, in that speech, many phrases and clauses were unnecessarily repeated more than twice in the same sentence.

(28) "I know what I believe. I will continue to articulate what I believe and what I believe I believe what I believe is right" (Bush, 2001)

\begin{tabular}{lll}
\hline Target & Error & Error Type \\
\hline $\begin{array}{l}\text { The subordinate clause } \text { what I } \\
\text { believe should be economized. }\end{array}$ & $\begin{array}{l}\text { The subordinate clause } \text { what I } \\
\text { believe is repeated many times }\end{array}$ & Repetition \\
\hline
\end{tabular}

On July 22, 2001, Bush attended the G-8 economic summit. He met Pope John Paul II, Prime Minister Berlusconi, and Vladimir Putin. In a news conference with Putin, Bush declared his reassured testimony to his simple religious faith. He asserted that he used to say what he believed; and what he believed was always right. He repeated the subordinate clause what I believe many times.

(29) "It is where children from all over America learn to be responsible citizens, and learn to have the skills necessary to take advantage of our fantastic opportunistic society." (George W. Bush, White House, May 1, 2002)

\begin{tabular}{lll}
\hline Target & Error & Error Type \\
\hline a society with fantastic opportunities & fantastic opportunistic society & Out-of-context \\
\hline
\end{tabular}

In May 2002, Bush was asked in a press conference about the educational reforms that he wanted to introduce to the American educational system. He explained that his educational reforms aimed at giving the American children the necessary skills to take advantage of the opportunities provided by the American society. However, he described America as a fantastic opportunistic society. The word opportunistic is semantically incorrect as it means to take immediate advantage, often unethically, of any circumstance of possible benefit. Semantically, Bush meant to say something like 'a society of fantastic opportunities'.

(30) "I know the human being and fish can coexist peacefully." (Bush, 2000)

\begin{tabular}{lll}
\hline Target & Error & Error Type \\
\hline $\begin{array}{l}\text { The dams would not be removed in } \\
\text { order not to endanger fish wealth. }\end{array}$ & $\begin{array}{l}\text { The human being and fish can } \\
\text { coexist peacefully. }\end{array}$ & Out-of-context \\
\hline
\end{tabular}

In 2000, Bush gave a speech about his energy policy. He said that he would not support the removal of energy-producing dams. It was simply because the removal of these dams would endanger fish. He was speaking perfectly till he began to deviate from the prepared text. He said that fish and human beings could live peacefully together. The sentence was semantically illogical to the audience.

(31) "If you don't stand for anything, you don't stand for anything! If you don't stand for something, you don't stand for anything." (Bush, 2000)

\begin{tabular}{lll}
\hline Target & Error & Error Type \\
\hline $\begin{array}{l}\text { A man who stands for nothing will } \\
\text { fall for anything. }\end{array}$ & $\begin{array}{l}\text { If you don't stand for anything, } \\
\text { you don't stand for anything. }\end{array}$ & Tautology \\
\hline
\end{tabular}


At Bellevue Community College, Bush elaborated the reforms he wanted to introduce to the social security system. At the end of his speech, he pointed out that a man who stands for nothing would fall for anything. That is, one's strong values prevent him/her from being persuaded by someone else's wrong beliefs. However, Bush repeated what he said twice using different words (i.e. tautology).

(32) "Our enemies are innovative and resourceful, and so are we. They never stop thinking about new ways to harm our country and our people, and neither do we." (George W. Bush, Washington, D.C., August 5, 2004)

\begin{tabular}{lll}
\hline Target & Error & Error Type \\
\hline $\begin{array}{l}\text { Neither do we stop thinking about new ways to harm } \\
\text { the terrorists }\end{array}$ & Neither do we & Out-of-context sentence \\
\hline
\end{tabular}

In 2004, in a news conference with Donald Rumsfeld, Bush announced that he signed a new law, according to which the military budget would be raised by 3.5 percent. However, Bush made an out - of - context mistake as he decided to deviate from the prepared text. What he added to the script meant that his administration would not stop thinking of new ways for causing harm to the Americans.

(33) 'I'm telling you there's an enemy that would like to attack America, Americans, again. There just is. That's the reality of the world. And I wish him all the very best." (Bush, 2009)

\begin{tabular}{lll}
\hline Target & Error & Error Type \\
\hline wish Obama & wish him & Out-of-context sentence \\
\hline
\end{tabular}

In his last news conference, Bush was asked about his expectations concerning what Obama was going to do in his first term. Bush replied that he could not speculate such a matter. But, he reminded Obama that there was an enemy that was getting ready for attacking America again. Bush used the object pronoun him referring to Obama, just immediately after warning him from the assumed enemy.

(34) "We are strong, we are determined, we are patient. We are resolved to rout out terror wherever it exists to save the world from freedom." (Bush, 2002)

\begin{tabular}{lll}
\hline Target & Error & Error Type \\
\hline from terrorism & from freedom & Out-of-context sentence \\
\hline
\end{tabular}

While Bush was addressing high school students, he said that America's message was to save the world from any terrorist attacks. But he slipped saying that America's message was to save the entire world from freedom.

\subsection{Speech Disfluencies}

(35) "I believe there ought to be, you know, one person in the klieg lights at a time, and I've had my time in the klieg lights. You know, I'm confident, you know, you'll catch me opining on occasion, but I wish him all the best." (Bush, 2009)

(36) "You know, Mike, I don't know. Probably the next day. I'm a Type A personality, you know, I just-I just can't envision myself, you know, the big straw hat and Hawaiian shirt sitting on some beach.” (Bush, 2009)

\begin{tabular}{lll}
\hline Target & Error & Error Type \\
\hline Underlined fillers should be economized & You know & Discourse markers \\
\hline
\end{tabular}

The excerpts in (35) and (36) were said by Bush in his last news conference; the one that included many filled pauses, such um, and well. In that news conference, Bush was asked about what he was going to do after leaving the White House. Bush said that he would show up every now to give his opinions and comments on serious matters going on in America. In (36), he said that he would not spend his time on beaches. Bush in that news conference noticeably used a large number of discourse markers, particularly you know. 


\section{Results and Discussion}

Before analyzing Bush's errors statistically and psychologically, the sample of errors collected is going to be subjected to the normality test. The aim of this test is to show that the sample of errors collected is really representative to Bush's errors. Table 1 shows that the six types of errors are subjected to the normality test. Table 2 shows that the data collected passed the normality test since the probability value (P-value) is $12 \%$ which is more than $5 \%$ (i.e., the significance level).

Table 1. Case processing summary

\begin{tabular}{llllll}
\hline Cases & \multicolumn{3}{c}{ Total } \\
\hline Valid & \multicolumn{3}{c}{ Missing } & \multicolumn{3}{l}{ Percent } \\
\hline $\mathrm{N}$ & Percent & $\mathrm{N}$ & Percent & $\mathrm{N}$ & $100.0 \%$ \\
6 & $100.0 \%$ & 0 & $0.0 \%$ & 6 & \\
\hline
\end{tabular}

Table 2. Kolmogorov-Smimov test

\begin{tabular}{llll}
\hline Speech Error & \multicolumn{3}{l}{ Kolmogorov-Smirnov } \\
\cline { 2 - 4 } Number & Statistic & Df & Sig. \\
\cline { 2 - 4 } & .292 & 6 & .120 \\
\hline
\end{tabular}

Figure 1 below shows a graphic distribution to a sample of speech errors made by George Bush. The main facts that this graph shows can be summed up in the following points: (a) syntactic errors are the most recurrent type of errors, rating 10 out of 36; (b) the speech disfluencies are the least recurrent type of errors, rating 2 out of 36; (c) the morphological and semantic errors come second in rate after the syntactic ones as the most recurrent types of errors, rating 9 for each out of 36; and (d) the cognitive intrusions and phonological errors come second in rate after speech disfluencies as the least recurrent types of errors produced by Bush, rating 3 for each out of 36.

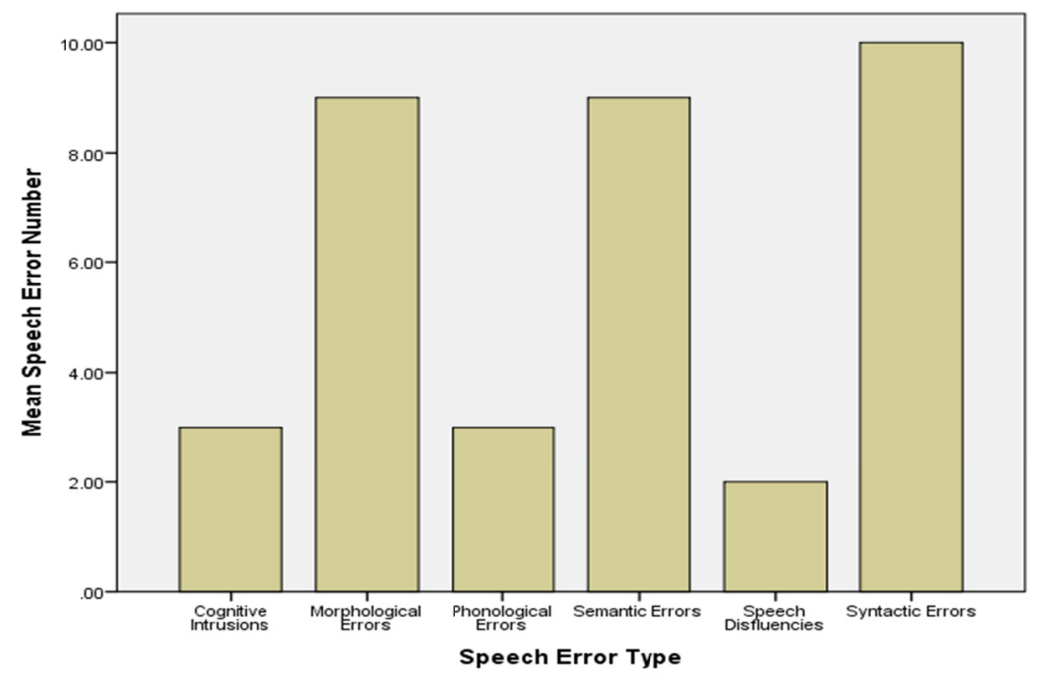

Figure 1. Bush's error frequencies

Figure 2 below shows the graphic distribution of Bush's syntactic errors. It proves that Bush has a serious problem with subject-verb agreement. Moreover, it proves that Bush cannot tell the difference between countable and uncountable nouns. Figure 3 shows that out-of-context errors are Bush's most recurrent semantic errors. 


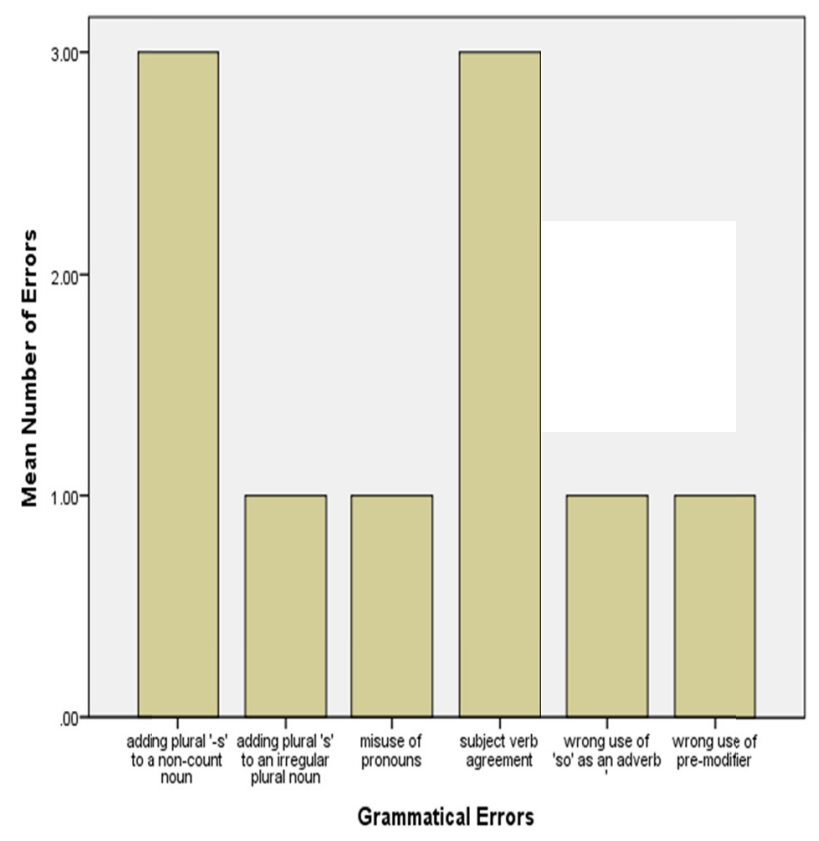

Figure 2. Bush's grammatical errors

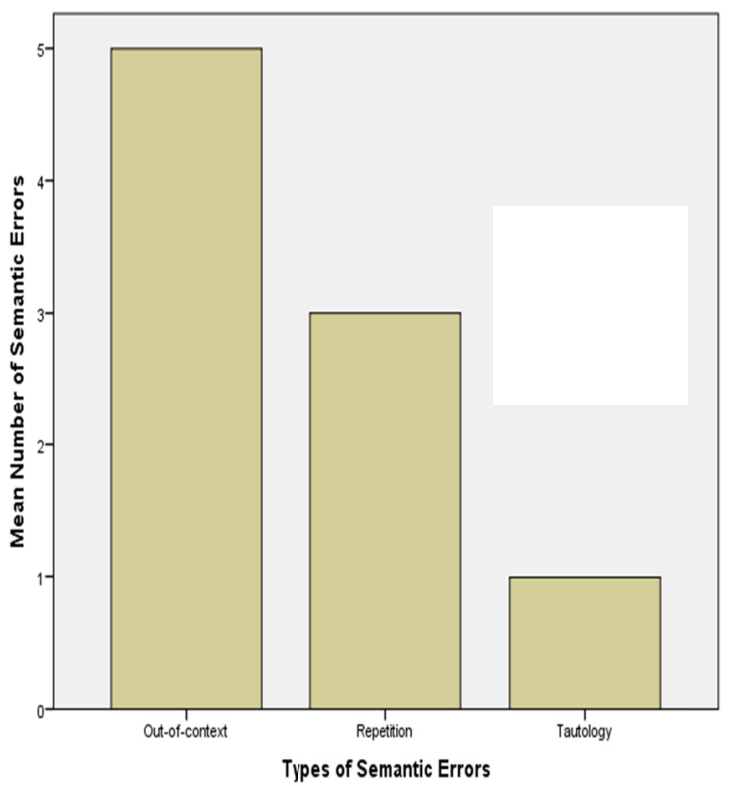

Figure 3. Bush's semantic errors

The Connectionist Theory (Dell et al., 1999) is used to analyze Bush's speech errors. This theory is chosen as it permits the bi-directional flow of information. In other words, the bottom-up and the top-down flow of information are both allowed in the processing. Dell et al. assert that there are four main layers of processing: semantic, syntactic, morphological, and phonological. These levels work in parallel and in series, with activation at each level. The errors can occur at any of these stages. In this theory, speech is produced by a number of connected nodes which represent distinct units of speech. The distinct units of speech may be phonemes, morphemes, syllables, or concepts. Further, these nodes interact with one another in any direction, from the semantic level to the lexical level and ultimately to the phonological level. The error in (37) below represents one of Bush's morphological errors, termed malapropism in psycholinguistics. The target word destruction is replaced with the erroneous word production. Following Dell et al. (1999), speech production begins with concepts, the idea of a word. This idea would activate all the words with similar features. That is, when the idea 
of destroying something is selected, all of the nodes representing this idea such as morphemes, phonemes, semantics and syntax are activated, and this activation spreads to the adjacent nodes until one node, the node that is most highly activated is selected for the output string. Namely, when Bush selected the word destruction, all the nodes representing this word are activated.

The words production and direction are activated as they are phonologically similar to the target word, and the word construction is activated as it is, semantically, the opposite of the target. These words are activated at the lexical level that comprises two levels: the syntactic and the morphological. The nodes direction, production, construction, and destruction begin to compete for activation at the same level. The competition between the nodes often leads to the activation of the wrong node.

(37) "The law I sign today directs new funds and new focus to the task of collecting vital intelligence on terrorist threats and on weapons of mass production." (George W. Bush, Washington, D.C., November 27, 2002.).

The errors in (38) and (39) show that non-count nouns and irregular plural nouns are improperly lexicalized. For example, the word internet is lexicalized a countable noun; whereas the word children is lexicalized as a singular regular countable noun. Therefore, when non-count nouns and irregular countable nouns are retrieved, a morphological interference takes place. This morphological interference takes the form of the plural '-s' morpheme. The errors in (38) and (39) below are errors of competence rather than performance.

(38) "We can have filters on internets where public money is spent." (George W. Bush, October 17, 2000)

(39) "As yesterday's positive report card shows, childrens do learn when standards are high and results are measured." (George W. Bush, New York, September 26, 2007)

A semantic error such as (40) below is due to the fact that the message or the idea is not well crystallized in the speaker's mind; therefore, the speaker retrieves many words at the semantic level, but all retrieved words are not semantically related. The retrieval of non-semantically related units may be a result of fatigue or distraction as Akram (2013) points out.

(40) "I know the human being and fish can coexist peacefully." (George W. Bush, Michigan, September 29, 2000)

Psychologically, Freud tries to explain why phonological, semantic and morphological speech errors take place. Further, he tries to point out the implications of the excessive occurrence of these errors. He generally points out that "a suppression of a previous intention to say something is the indispensable condition for the occurrence of a slip of the tongue" (Reason, 2000, p. 610). That is, a slip of the tongue occurs as a result of the continuous suppression of a wish or a desire. For Reason (2000), Freud pays much attention to a particular type of errors called parapraxes, known later as Freudian slip. It is an error in speech, memory, or physical action that is interpreted as occurring due to the interference of an unconscious repressed wish, conflict, or train of thought. This suppression is guided by the ego and the rules of correct behavior. In addition to thought or emotion suppression, there are some psycho-physiological factors that lead to the occurrence of speech errors. These factors embrace fatigue, excitement, strong associations, distraction, and preoccupation and the like.

In contrast to psychoanalytic theorists, such as Freud, cognitive psychologists pay much attention to grammatical slips. They assume that grammatical slips represent a sequencing conflict in grammar production system. They attribute such a conflict to inattention, insufficient knowledge, and banalisation. Actually, banalization, for Reason (2000), means the replacement of unusual expressions with forms that are in more common use. As for George Bush's grammatical speech errors, it seems that they are due to insufficient knowledge rather than banalisation or inattention.

As for Bush's speech disfluencies, it should be noted that speech disfluencies indicate that the speech production apparatus requires time to search for the next word, phrase, or idea (Schachter, Christenfeld, \& Bilous, 1991). Since Bush's speech disfluencies are rated the least recurrent type of errors, it indicates that Bush is marked by rashness as he was not given himself time to think of what he was going to say. In addition, it is believed that speeches "that contain disfluencies pose problems for speech recognition systems" (Bortfeld, Leon, Bloom, Schober, \& Brennan, 2001, p. 124).

\section{Conclusion}

Depending on the previous sections, the research questions raised in this study can be answered as follows:

\section{1) What are the categories of errors made in Bush's spontaneous speeches?}

In the previous sections, 36 spontaneous speech errors made by George W. Bush have been categorized and studied via a psycholinguistic approach wherein the researcher has made use of the Connectionist Theory (Dell 
et al., 1999) to interpret the data collected. These errors have been categorized into six groups: (a) cognitive intrusions, meaning that "units from outside the message level are inserted into the utterance" (Levelt, 1989, p. 380), (b) phonological errors, (c) morphological errors, (d) syntactic errors, (e) semantic errors, and (f) speech disfluencies. Freudian slips, defined as the intrusion of unwanted thoughts, are the most recurrent type of cognitive intrusions found in Bush's spontaneous speeches. Phonological errors have been basically spoonerisms (i.e., switching of segments, morphemes or words) (Garrod, 2006), perseverations (i.e., the replacement of an earlier segment with a later one) (Carroll, 1986; Palmquist, 1981), and syllable substitution. The most notable type of morphological errors has been malapropisms (i.e. the replacement of a word with another that has similar sounds but an inappropriate meaning). The lack of subject-verb agreement has been the most notable syntactic error. As for semantic errors, they have categorized into repetitions, tautologies, and out-of-context errors, the ones that have notably exceeded all other types of semantic errors. The speech disfluencies, the final type of Bush's speech errors, have been basically discourse markers.

2) What are the psycholinguistic interpretations of Bush's speech errors?

The psycholinguistic interpretations of Bush's speech errors are outlined in the following table.

Table 3. Psychological interpretations of Bush's errors

\begin{tabular}{|c|c|}
\hline Speech Error Types & Psycholinguistic Interpretations \\
\hline $\begin{array}{l}\text { (a) Cognitive intrusions (i.e., } \\
\text { Freudian slips) }\end{array}$ & $\begin{array}{l}\text { 1) The interference of an unconscious repressed wish, conflict, or train of thought. } \\
\text { 2) Some psycho-physiological factors, such as fatigue, excitement, strong associations, } \\
\text { distraction, and preoccupation. }\end{array}$ \\
\hline $\begin{array}{l}\text { (b) Phonological speech errors } \\
\text { (c) Morphological speech errors }\end{array}$ & $\begin{array}{l}\text { Both phonological and morphological errors are due to a priming process (Dell et al., 1999). } \\
\text { Priming can be defined as "an implicit memory effect in which exposure to a stimulus influences } \\
\text { a response to a later stimulus" (Gulan \& Valerjev, 2010, p. 53). }\end{array}$ \\
\hline (d) Syntactic speech errors & $\begin{array}{l}\text { 1) Improper lexical insertion } \\
\text { 2) Insufficient knowledge (i.e. poor linguistic competence) }\end{array}$ \\
\hline (e) Semantic speech errors & Incorrect crystallization of the ideas as a result of fatigue or distraction. \\
\hline (f) Speech disfluencies & $\begin{array}{l}\text { 1) Bush has problems for speech recognition system. } \\
\text { 2) Rashness }\end{array}$ \\
\hline
\end{tabular}

\section{3) What can speech errors reveal about Bush's character?}

President George W. Bush is both one of the most popular and unpopular presidents in history of the United States of America. It is due to the fact that he has received the highest presidential approval ratings after the September 11 terrorist attacks, as well as one of the lowest approval ratings after the 2008 financial crisis. Internationally, he is an increasingly controversial person, with huge public protests taking place even during visits to close allies, such as the United Kingdom and France. Such a controversy has driven the researcher to do a research to try to settle this controversy via two linguistic tools: speech errors and body language. The speech errors made by George Bush reveal several aspects of his character. These aspects can be outlined in the following points: First, the phonological and morphological errors, caused by the psychological priming (i.e. an implicit memory or a non-conscious influence of past objects) reveal how much perplexity, confusion and pressure Bush underwent. Second, Bush's Freudian slips, caused by psycho-physiological factors, such as fatigue, excitement, and distraction, reveal the fact that he was not an open outright president as he repressed many thoughts and feelings more than he showed. Third, Bush's syntactic errors, caused by the improper lexical insertion, reveal his poor linguistic competence the matter that reveals low intelligence for many psychologists such as Pishghadam and Shams (2012). Fourth, the economical use of speech disfluencies in Bush's spontaneous speeches, caused by problems in the recognition system, reveals that he has a tendency of rashness.

\section{Acknowledgments}

This project was funded and supported by the Deanship of the Scientific Research at the Prince Sattam Bin Abdulaziz University; thank you very much for your generosity. I'd like to express my sincere appreciation to everyone who boosted me throughout the course of writing this paper: Dr. Mohammad Tohammy, my mentor; Dr. Shaker Rizk, a professor of linguistics; Dr. Abdulfattah Omar, associate professor of linguistics at Prince Sattam Bin Abdulaziz University.

\section{References}

Akram, S. (2013). Investigation of the Physical and Cognitive Factors Affecting Slip Error. International Journal 
of Computer and Information Technology, 2(5), September.

Andersson, I. (2005). American Political Rhetoric: A Study of Selected Speeches by George W. Bush. Lulea University of Technology, 32, 1-46.

Black, A. (2004). With God on Our Side: Religion in George W. Bush's Foreign Policy Speeches. In the Annual Meeting of the American Political Science Association; Chicago, Illinois.

Bonnefille, S. (2008). When green rhetoric and cognitive linguistics meet: President G. W. Bush's environmental discourse in his State of the Union Addresses (2001-2008). University of Tours, Metaphoric, 15, 1-61.

Bortfeld, H., Leon, S. D., Bloom, J. E., Schober, M. F., \& Brennan, S. E. (2001). Disfluency rates in spontaneous speech: Effects of age, relationship, topic, role, and gender. Language and Speech, 434(32), 122-124.

Clark, H., \& Clark, E. (1977). Psychology and Language: An Introduction to Psycholinguistics. New York: Harcourt, Brace, \& Jovanvich.

Daniel, P., \& Sam, A. (2011). Research Methodology. Gyan Publishing House.

Dell, G., Chang, F., \& Griffin, Z. (1999). Connectionist models of language production: lexical access and

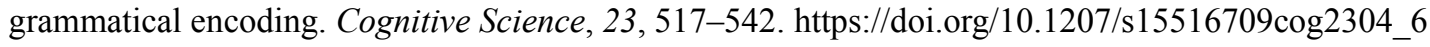

Fromkin, V. (1973). Speech errors as linguistic evidence. Los Angeles: California University.

Garnham, A. (2013). Psycholinguistics (PLE: Psycholinguistics). https://doi.org/10.4324/9780203729946

Greene, J. R. (2006). Crusade: The Rhetorical Presidency of George Bush (pp. 101-112). The Second Term of George W. Bush. https://doi.org/10.1057/9781403984418_6

Gulan, T., \& Valerjev, P. (2010). Semantic and related types of priming as a context in word recognition. Review of Psychology, 17(1), 53-58.

Hill, A. A. (n.d.). A Theory of Speech Errors. In V. A. Fromkin (Ed.), Speech Errors as Linguistic Evidence (pp. 205-214). https://doi.org/10.1515/9783110888423.205

Judis, J. (2005). The Chosen Nation: The Influence of Religion on U.S. Foreign Policy. Policy Brief, 37, 1-8.

Kean, T., \& Hamilton, L. (2004). The 9/11 Report: The National Commission on Terrorist Attacks Upon the United States. St. Martin's Paperbacks.

Kushner, S., \& Gershkoff, A. (2005). Shaping Public Opinion: The 9/11-Iraq Connection in the Bush Administration's Rhetoric. Perspectives on Policy, 3(3), 525-537. https://doi.org/10.1017/S1537592705050334

Levelt, W. (1989). Speaking from intention to articulation. Cambridge: MIT Press.

Long, E. (2009). George W. Bush and the US Supreme Court (pp. 44-58). Assessing the George W. Bush Presidency. https://doi.org/10.3366/edinburgh/9780748627400.003.0004

Marquit, M. (2005). Rhetorical use of fear by the Bush administration: The way George W. Bush persuaded the U.S. public to go to war. Syracuse University.

Martin, P., \& Midgley, E. (2003). Immigration: shaping and reshaping America. Population Bulletin. Population Reference Bureau, Washington, DC.

Nelson, M. (2017). 1. George Bush: Texan, Conservative. In M. Nelson \& B. A. Perry (Eds.), Inside the Presidency of George H. W. Bush (pp. 27-47). https://doi.org/10.7591/9780801470820-007

Palmquist, P. E. (1980). Spoonerism. History of Photography, 4(1), 38-38. https://doi.org/10.1080/03087298.1980.10441140

Pfiffner, J. (2004). George W. Bush: Policy, politics, and personality. In G. C. Edwards III \& P. J. Davies (Eds.), New Challenges for the American Presidency (pp. 161-181). New York: Longman.

Pishghadam, R., \& Shams, M. (2012). Hybrid Modeling of Intelligence and Linguistic Factors as Predictors of L2 Writing Quality: A SEM Approach. Language Testing in Asia, 3(2), 53-76. https://doi.org/10.1186/2229-0443-2-3-53

$\mathrm{Pu}, \mathrm{C}$. (2007). Discourse analysis of President Bush's speech at Tsinghua University, China. Intercultural Communication Studies, 15, 205-216.

Reason, J. (2000). The Freudian slip revisited. Psychologist-Leicester, 13(12), 610-611.

Rodriguez, A. (2006). Speeches and declarations: A war of words. Revista Alicantina de Estudios Ingleses, 19 , 
365-386. https://doi.org/10.14198/raei.2006.19.20

Rudalevige, A. (2006). George W. Bush and Congress in the Second Term: New Problems-Same Results (pp. 79-99)? The Second Term of George W. Bush. https://doi.org/10.1057/9781403984418_5

Schachter, S., Christenfeld, N., Ravina, B., \& Bilous, F. (1991). Speech disfluency and the structure of knowledge. Journal of Personality and Social Psychology, 60(3), 362-367. https://doi.org/10.1037/0022-3514.60.3.362

Woodward, B. (2002). Bush at War. Washington: Simon \& Schuster Rockefeller Center.

\section{Copyrights}

Copyright for this article is retained by the author, with first publication rights granted to the journal.

This is an open-access article distributed under the terms and conditions of the Creative Commons Attribution license (http://creativecommons.org/licenses/by/4.0/). 